$\mathrm{A} \int_{\text {ass }} \underset{0976-272 \times \mathrm{x}}{\mathrm{H}}$

Received : 25.07.2014

Revised : 21.10.2014

Accepted : 03.11.2014
Members of the Research Forum

Associated Authors:

${ }^{1}$ Department of Floriculture and

Landscaping, Punjab Agricultural

University, LUDHIANA (PUNJAB)

INDIA

Author for correspondence : PARMINDER SINGH

Department of Floriculture and

Landscaping, Punjab Agricultural

University, LUDHIANA (PUNJAB)

INDIA

Email : sahai_p@yahoo.com
THE ASIAN JOURNAL OF HORTICULTURE

Volume 9 | Issue 2|Dec., 2014|377-381

Visit us -www.researchjournal.co.in

\title{
Effect of shade levels on growth and frond production in boston fern [Nephrolepis exaltata (L.) Schott]
}

\section{PARMINDER SINGH, R.K. DUBEY ${ }^{1}$ AND KUSHAL SINGH ${ }^{1}$}

ABSTRACT : Plants of Nephrolepis exaltata (L.) schott cv. BOSTONIENSIS were grown under three different shade levels i.e. under open field conditions as well as under 50 per cent and 75 per cent shade. Basal dose of 25 tones of FYM/ha was given at the time of planting, whereas, nitrogen was applied at $250 \mathrm{~kg} / \mathrm{ha}$ in four equal splits at quarterly intervals. Under open field conditions, growth of the plants was severely affected during both the extremes. The best growth was obtained under 75 per cent shade and the plants exhibited most vigorous growth and produced the highest numbers of fronds during both the growing years. Under 50 per cent shade, average frond length and mean lamina length were higher than the other two treatments. This however, was compensated for by higher number of fronds produced under 75 per cent shade.

KEY WORDS : Nephrolepis exaltata, Shade levels, Frond production

HOW TO CITE THIS ARTICLE : Singh, Parminder, Dubey, R.K. and Singh, Kushal (2014). Effect of shade levels on growth and frond production in boston fern [Nephrolepis exaltata (L.) Schott]. Asian J. Hort., 9(2) : 377-381. 